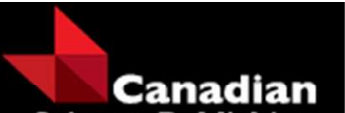

Science Publishing

Canadian Journal of Forest Research

Revue canadienne de recherche forestière

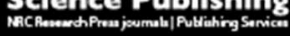

\title{
Gallery success, brood production and condition of mountain pine beetles (Coleoptera: Curculionidae) reared in whitebark and lodgepole pine from Alberta, Canada
}

\begin{tabular}{|r|l|}
\hline Journal: & Canadian Journal of Forest Research \\
\hline Manuscript ID & cjfr-2015-0351.R1 \\
\hline Manuscript Type: & Article \\
\hline Date Submitted by the Author: & 22-Dec-2015 \\
\hline Complete List of Authors: & $\begin{array}{l}\text { Esch, Evan; University of Alberta, Renewable Resources } \\
\text { Langor, David; NRCan - Canadian Forest Service } \\
\text { Spence, John; University of Alberta, Renewable Resources }\end{array}$ \\
\hline Keyword: & whitebark pine, host effects, rearing, mountain pine beetle, population \\
\hline
\end{tabular}

SCHOLARONE ${ }^{\text {TH }}$

Manuscripts 
1 i) Gallery success, brood production and condition of mountain pine beetles (Coleoptera:

2 Curculionidae) reared in whitebark and lodgepole pine from Alberta, Canada

3 ii) Evan D. Esch, David W. Langor and John R. Spence

4

5 iii) Evan D. Esch M. Sc.: Department of Renewable Resources, University of Alberta, 442

6 Earth Sciences, Building, Edmonton, Alberta, Canada, T6G 2H1. e-mail: eesch@ualberta.ca

8 David W. Langor Ph. D.: Natural Resources Canada, Canadian Forest Service, 5320-122

9 Street, Edmonton, Alberta, Canada, T6H 3S5. e-mail: dlangor@nrcan.gc.ca

10

11 John R. Spence Ph. D.: Department of Renewable Resources, University of Alberta, 442

12 Earth Sciences, Building, Edmonton, Alberta, Canada, T6G 2H1. e-mail:

13 jspence@ualberta.ca

14

15 iv) Corresponding author, Evan D. Esch: Department of Renewable Resources, University of

16 Alberta, 442 Earth Sciences, Building, Edmonton, Alberta, Canada, T6G 2H1 Phone: 780-

17 982-9117, Fax: 780-492-1767, e-mail: eesch@ualberta.ca

18 
19 Breeding pairs of mountain pine beetles (Dendroctonus pondersoae Hopkins) were

20 introduced into freshly cut bolts of whitebark pine (Pinus albicaulis Engelmann) and

21 lodgepole pine (Pinus contorta Douglas ex Loudon var. latifolia Engelmann) in the

22 laboratory. Brood adults emerging from the bolts were collected and galleries were dissected

23 to compare reproductive success, brood production and adult condition between the two

24 pines. Beetles were more likely to establish egg galleries that produced brood in lodgepole

25 than in whitebark pine. Larval gallery density/cm egg gallery was significantly higher in

26 whitebark pine than in lodgepole pine; however, egg galleries also tended to be shorter in

27 whitebark pine bolts, and consequently, brood production per gallery did not differ between

28 the two host species. Female body size, female mass and female fat content of brood adults,

29 and survival from larva to adult did not differ between beetles reared in the two hosts.

30 Though this no-choice assay did not simulate the sequence of events occurring during host

31 selection, these data may suggest that beetles could be less likely to attack whitebark pines in

32 southwestern Alberta. Whitebark pines that are attacked will produce brood in similar

33 numbers and condition as those from lodgepole pines. 


\section{Introduction}

The mountain pine beetle, Dendroctonus ponderosae Hopkins (Coleoptera:

Curculionidae) is considered the most destructive forest insect in western North America (Furniss and Carolin 1977). This beetle infests 22 species of pines in several forest types and eco-regions from Baja Norte, Mexico $\left(31^{\circ} \mathrm{N}\right)$ to northern Alberta and British Columbia $\left(58^{\circ} \mathrm{N}\right)$ (, Furniss and Schenk 1969, Smith et al. 1981, Wood 1982, Amman and Cole 1983, Safranyik et al. 2010). The biology, population dynamics and ecological roles of mountain pine beetle are best understood in forest types where the species has most commonly caused large-scale outbreaks. These forest types are typified as being even-aged, dominated by lodgepole pine (Pinus contorta Douglas ex Loudon var. latifolia Engelmann) or ponderosa pine (Pinus ponderosa Douglas ex Lawson), > 80 years old and growing between $800 \mathrm{~m}$ and $1400 \mathrm{~m}$ asl $\left(49^{\circ} \mathrm{N}-55^{\circ} \mathrm{N}\right)$ (Reviewed in Safranyik and Carroll 2006).

The recent expansion of the mountain pine beetle into more northern forests, higher elevation forests (Carroll et al. 2004) and jack pine (P. banksiana Lamb) containing forests (Cullingham et al. 2011) in western Canada is purportedly related to anthropogenic factors, including fire suppression, which have resulted in huge areas of overmature stands, and winter warming due to climate change (Taylor and Carroll 2004, Safranyik et al. 2010). This expansion into new areas formerly unfavorable for the beetle has generated much discussion and interest (e.g., Cudmore et al. 2010, Safranyik et al. 2010). The mountain pine beetle has a highly adaptable life history (Bentz et al. 1991, 2010) and exhibits relatively consistent features in outbreak dynamics across a broad geographic and host range (Cole and Amman1980, Amman 1984); however, new research indicates that in these newly invaded forest types key aspects of the beetle's biology (Myrholm and Langor 2015), population dynamics (Bentz and Schen-Langenheim 2007) and ecological influences differ compared to that in the altitudes and latitudes the beetle has typically occupied in the last century 
60 (Safranyik et al. 2010). The dramatic expansion of the mountain pine beetle into northern

61 Alberta and British Columbia and eastward into the boreal forest has garnered most of the 62 attention (e.g., Kurz et al. 2008, Bentz et al. 2010). While sustained outbreaks at high

63 altitudes in other parts of the range are not completely unprecedented (Logan and Powell

64 2001), they represent a significant deviation from typical patterns of mountain pine beetle

65 activity recorded in the last 125 years (Arno and Hoff 1989), are also thought to be related to

66 climate (Carroll et al. 2004, Logan et al. 2010) and are potentially as devastating as

67 expansion to more northern lattitudes (Tomback et al. 2001, ASRD and ACA 2007, Logan et

68 al. 2010).

69 During the past century mountain pine beetle outbreaks were infrequent in high

70 elevation, subalpine forests of western North America, and were typically associated with

71 prolonged periods of unseasonably warm summer and winter temperatures (Logan and

72 Powell 2001). Several endangered and/or threatened five needle pines, some with current or

73 pending formal conservation listing, thrive in these high-altitude forests (Gibson et al. 2008),

74 including whitebark pine (Pinus albicaulis Engelmann), that are sensitive to changes in

75 disturbance regimes because they grow slowly and mature late in life. As whitebark pine is a

76 foundational (Ellison et al. 2005) and keystone (Tomback et al. 2001) species in sub-alpine

77 zones, and is listed as endangered in Canada (COSEWIC 2010), the recent outbreak of

78 mountain pine beetle in high altitudes is a cause for special concern (ASRD and ACA 2007).

79 The severity and nature of mountain pine beetle impact on whitebark pine depends on

80 interactions between the beetle and its host, as moderated by the environment. Important life

81 history features of the mountain pine beetle (e.g., survival, fecundity, condition,

82 development) have been shown to vary among host tree species (Amman 1982, Langor 1989,

83 Cerezke 1995), and such differences ultimately determine host suitability, and directly

84 influence mountain pine beetle population dynamics and success. 
There are relatively few empirical data about the quality of whitebark pine as a host

86 for the mountain pine beetle. In laboratory rearings, Amman (1982) found that whitebark

87 pines bolts produced more and larger brood compared to lodgepole pines (though these

differences were not statistically significant) while, Gross (2008) found that lodgepole pine

bolts produced significantly more brood than whitebark pines while whitebark pines

90 produced larger beetles. Both studies are based on host material from only one or two trees of

91 each host species and did not adequately control for variation in phloem thickness, thus

92 different results could simply reflect natural variation within a tree species. Therefore, to

93 increase understanding of the suitability of whitebark pine as a host for the mountain pine

94 beetle in the northern part of the ranges of both species, we undertook a laboratory rearing

95 study. We compared the life history and reproductive characteristics egg gallery success,

96 brood production and brood adult size, mass and fat content, between mountain pine beetles

97 reared in bolts of whitebark pine and lodgepole pine. We interpreted these responses as

98 indicators of host quality for the beetle. This work compliments studies of mountain pine

99 beetle success in standing trees of each species (Esch 2012) and comparisons of the natural

100 enemies associated with the beetle found in each of these host trees (Esch et al. 2015).

\section{Materials and Methods}

used as parental stock for rearings were collected from six naturally infested lodgepole pines

104 near Eureka River, in northern Alberta $\left(56.4799^{\circ} \mathrm{N}, 118.5177^{\circ} \mathrm{W}\right)$ on 4 September 2008.

105 Infested bolts were sealed with paraffin wax to prevent desiccation, held at $5^{\circ} \mathrm{C}$ until 20

106 October 2008 and then moved to a greenhouse for larvae to complete development. Bolts

107 were placed in large ventilated plastic rearing containers (modified 110-litre black garbage

108 cans) in the greenhouse, and held at 18 to $22^{\circ} \mathrm{C}$ under a $12 \mathrm{~L}: 12 \mathrm{D}$ photoperiod. Emerging

109 beetles were collected daily from the rearing containers, placed in Petri plates lined with fresh 
110 pine phloem [sexes separated according to Lyon (1958)], and stored in the dark in a cooler at $1118^{\circ} \mathrm{C}$ until used.

112 Host material for rearing mountain pine beetles was collected near Vickary Creek in

113 southern Alberta $\left(49.7757^{\circ} \mathrm{N}, 114.5282^{\circ} \mathrm{W}\right)$. These trees were located on an east-facing

114 slope, at 1950 m elevation, situated in a stand dominated by Engelmann spruce, Picea

115 engelmannii Parry ex Engelmann, and subalpine fir, Abies lasiocarpa (Hooker) Nuttall, and

116 with approximately equal parts of whitebark pine and lodgepole pine representing minor

117 components (ca., 30\%) of the canopy. Although exact composition was not recorded, the

118 stand was similar to a minor seral whitebark pine community described by Arno and Hoff

119 (1989). Ten whitebark pines [diameter at breast height (DBH) 20-31 cm] and 10 lodgepole

120 pines (DBH 19-29 cm) with no visible signs of insect damage or disease were felled on 22

121 and 23 September 2008, and each felled tree was used as a source of 2-3 bolts (each $1.1 \mathrm{~m}$ in

122 length) for rearing beetles as described below. Bolts were transported to the Canadian Forest

123 Service, Northern Forestry Centre in Edmonton, Alberta, and held in a greenhouse at18 to

$12422^{\circ} \mathrm{C}$ under $12 \mathrm{~L}: 12 \mathrm{D}$ photoperiod for the duration of this experiment.

125 Gallery Initiation and Beetle Collection. The bark surface of each bolt used for

126 rearing was divided into $1-3$ strips, each $1.1 \mathrm{~m}$ long and $\geq 30 \mathrm{~cm}$ wide, depending on bolt

127 circumference, by cutting longitudinal grooves with a chainsaw through the bark ca. $1 \mathrm{~cm}$

128 into the sapwood. Previous experience suggested that this allowed the beetles to feed ad

129 libitum while having their area of activity constrained (Langor, unpublished). Paraffin wax

130 was used to seal the ends and grooves of each bolt to slow desiccation and reduce infection

131 by saprophytic fungi.

132 We attempted to establish one mountain pine beetle gallery in each bark strip on each

133 bolt as follows. A newly emerged female beetle of average size (conspicuously small and

134 large beetles were discarded) and good condition (actively moving about the Petri plate) was 
135 placed in a small hole scored into the bark and phloem ca. $30 \mathrm{~cm}$ from the base of the bolt.

136 The hole was then sealed with one half of a large gelatin capsule attached to the bolt with a 137 pin to prevent female escape. After $24 \mathrm{~h}$, each hole was checked for gallery initiation, as

138 indicated by boring dust in the gelatin capsule. Females failing to initiate a gallery after $24 \mathrm{~h}$

139 were re-inserted into their hole, while dead females were replaced with fresh females.

140 After gallery construction proceeded to the point where females were no longer

141 visible at the entrance of their gallery, a male was inserted into the gallery entrance and the

142 gelatin capsule was replaced to prevent escape. Capsules were checked again after $24 \mathrm{~h}$ and

143 dead or rejected males were replaced by new males. This procedure was repeated daily for

144 seven days, after which we stopped attempting to initiate galleries in those bark sections

145 where galleries were apparently not established. In total, we attempted to establish 36

146 galleries in 18 lodgepole pine bolts and 46 galleries in 20 whitebark pine bolts.

147 After gallery initiation was complete, each bark strip was individually caged with 1

$148 \mathrm{~mm}^{2}$ nylon screen. To accomplish this, wooden slats $(\mathrm{ca} .1 \mathrm{~cm}$ thick, $3 \mathrm{~cm}$ high, and the

149 length of the bolt) were inserted into the chainsaw grooves on each bolt, thereby providing

150 'sides' to each bark strip. Then nylon screen was glued and stapled to the top and ends of

151 each slat and to the top end of the bolt. The screen at the bottom end of each cage was formed

152 into a funnel-shape, fit with a collecting jar and then sealed to the bolt with glue and staples

153 to prevent beetle escape. $\mathrm{F}_{1}$ adults (hereafter called 'brood adults') began emerging 47 days

154 after the end of the gallery initiation period and continued emerging for 36 days. Brood adults

155 were collected daily, placed in individual $1.5 \mathrm{ml}$ microcentrifuge tubes, and stored at $-20^{\circ} \mathrm{C}$

156 for subsequent analysis. Parent beetles emerging during this 36 day period could not be

157 distinguished from brood adults.

158 Gallery Dissection and Beetle Condition. After brood adults stopped emerging, the

159 total number of emergence holes was recorded for each gallery. Differences in the number of 
160 emergence holes and captured beetles indicate as many as $26 \%$ of brood adults may have

161 escaped the cages by chewing through the mesh, despite our best efforts to seal the bark

162 strips. Because of this discrepancy, we used the number of emergence holes as a measure of

163 brood production, knowing that this number likely underestimates emergence (Amman and

164 Cole 1983). A piece of unconsumed phloem was excised from each bolt and its thickness was

165 measured with calipers $(0.01 \pm 0.005 \mathrm{~cm})$ and the size of each bolt was measured using a

166 DBH tape $(0.1 \pm 0.05 \mathrm{~cm})$. We measured phloem thickness at the end of the experiment to

167 limit infection by saprophytic fungi. Although it may have introduced some experimental

168 error, we assumed that phloem desiccated similarly between the two species. The bark was

169 then peeled so that egg gallery length and number of larval galleries could be recorded.

170 Unfortunately, number of eggs laid per gallery (fecundity) could not be reliably assessed

171 because it was impossible to accurately tally dead eggs or identify egg niches in phloem

172 degraded by saprophytic fungal activity. Consequently, oviposition could not be used reliably

173 as the criterion for successful gallery initiation; instead we used presence of at least one larval

174 gallery. The larval gallery density was determined from the number of larval galleries per $\mathrm{cm}$

175 of egg gallery assessed over the entire egg gallery. Larval survival was estimated from the

176 number of emergence holes per bark strip divided by the number of larval galleries per egg

177 gallery.

178 Nine hundred and fourty six brood adults were collected. From these, the 466

179 females beetles were retained to assess brood adult condition. Pronotum width was measured

180 to the nearest $0.1 \pm 0.05 \mathrm{~mm}$, using a dissecting microscope (K series, Motic, Xaimen, China)

181 fitted with an ocular micrometer. Beetles were dried at $75^{\circ} \mathrm{C}$ for $24 \mathrm{~h}$ and then weighed to the

182 nearest microgram using a balance (Sartorius model CP2P, Elk Grove, IL). Fat content was

183 determined as the difference in dry mass before and after fat extraction in a Soxhlet

184 apparatus. To accomplish this, beetles were individually placed in perforated $1.5 \mathrm{ml}$ 
185 microcentrifuge tubes that were then heated in a Soxhlet apparatus (45/50 Pyrex, Fischer

186 Scientific, Toronto, ON, Canada) while immersed in petroleum ether for $8 \mathrm{~h}$ at $35-60^{\circ} \mathrm{C}$.

187 Beetles were returned to the drying oven a second time for $24 \mathrm{~h}$ at $75^{\circ} \mathrm{C}$ and re-weighed to 188 determine fat loss.

189 Statistical Analysis. All parameters measured from each attempted or successful

190 gallery were averaged to give a single value for each tree and values were compared between

191 host species. Differences in tree diameter (average of all bolts) and phloem thickness of each

192 tree (average of all bolts) was tested using a Welch's $t$-test. The effect of host species on

193 proportion of successful egg galleries was tested using a Generalized Linear Mixed Model

194 (GLMM) that included phloem thickness as a random effect (random intercept) and normally

195 distributed errors $\left.\mathrm{N}\left(\mu, \sigma^{2}\right)\right)$. Relationships between gallery success and phloem thickness were

196 investigated with Pearson's correlations. Since not all bark strips contained successful

197 galleries, sample size was too small (nine lodgepole pine trees and six whitebark pine trees)

198 to include phloem thickness as a random effect for models of the other parameters measured

199 in this experiment. The effects of host species on egg gallery length, number of larval

200 galleries per egg gallery, larval gallery density, brood survival, sex ratio, brood adult

201 emergence, as well as female brood adult size, mass and fat content were tested by General

202 Linear Models (GLM). GLMs were fit by restricted maximum likelihood estimates, while the

203 GLMM was fit by penalized quasi-likelihood estimates (see Bolker et al. 2009). Wald's $t$ -

204 values were used to assess significance of model parameters. All analyses were performed in

205 R version 2.15.3 (R Development Core Team 2013) using the nlme (Pinheiro et al. 2008) and

206 MASS (Venables and Ripley 2002) packages following procedures outlined by Zuur et al.

207 (2009). 
Results

Host Material. Diameter of bolts used in this study ranged from 15 to $31 \mathrm{~cm}$. There was no difference between host species in tree diameter (lodgepole pine: $22 \pm 0.7 \mathrm{~cm}$ (mean

$211 \pm \mathrm{SE}$ ); whitebark pine: $26 \pm 1.7 \mathrm{~cm} ; t=1.79, \mathrm{df}=15.3, p=0.098)$ or phloem thickness

212 (lodgepole pine bolts: $1.1 \pm 0.09 \mathrm{~mm}$; whitebark pine bolts: $1.3 \pm 0.15 \mathrm{~mm}$; $t=0.585$, $213 \mathrm{df}=15.3, p=0.567)$.

214 Gallery Success. Egg gallery success varied between host species. Of the 82 215 attempted egg galleries, 21 pairings from nine lodgepole pine trees and 13 pairings from six 216 whitebark pine trees produced brood. The proportion of successful egg galleries on lodgepole 217 pines was significantly higher than on whitebark pines ( $t=2.11 \mathrm{df}=17, p=0.049$; Fig. 1A).

218 Overall, the proportion of successful egg galleries tended to increase with phloem thickness $219(\rho=0.535, \mathrm{df}=18, p=0.015)$. This correlation was statistically significant in whitebark pine 220 bolts $(\rho=0.898, \mathrm{df}=8, p<0.001)$ but not in lodgepole pine bolts $(\rho=0.416, \mathrm{df}=8, p=0.231)$. For

22117 of the 48 unsuccessful pairings (35\%, 12 pairings in whitebark and five in lodgepole), no 222 egg galleries were excavated into the phloem or sapwood. In the remaining 31 unsuccessful pairings, egg galleries were initiated but were short $(1-15 \mathrm{~cm})$ with either one parent (eight pairs in whitebark and six in lodgepole) or both parents dead in the gallery (one pair in lodgepole), or seemingly abandoned by both parents (12 in whitebark and five in lodgepole).

Gallery Characteristics. Egg gallery lengths were not statistically different between lodgepole pine $(41.0 \pm 2.74 \mathrm{~cm})$ and whitebark pine $(32.2 \pm 6.90 \mathrm{~cm})(t=1.00 \mathrm{df}=14$,

$228 p=0.334$; Fig. 1B). The total number of larval galleries per egg gallery in lodgepole pine $229(63.9 \pm 11.31)$ was not significantly different $(t=0.28 \mathrm{df}=14, p=0.785)$ from that in whitebark 230 pine bolts $(68.9 \pm 13.22)$. Larval gallery density was significantly greater in whitebark pine

$231(3.1 \pm 0.44$ galleries $/ \mathrm{cm})$ than in lodgepole pine $(1.8 \pm 0.19)(t=2.818 \mathrm{df}=14, p=0.015 ;$ Fig. $2321 \mathrm{C})$. 
Brood Adult Production. Brood adult emergence was a function of both parental

234 fecundity and larval survival. Brood adults emerged from all successful galleries except one 235 (in lodgepole pine) where all larvae died as early instars. There was no significant host effect on successful larval development from L1 to adulthood ( $t=1.11 \mathrm{df}=14, p=0.287$; Fig. 1D), although there was a trend for higher success in lodgepole pine, $66.1 \pm 8.29 \%(\mathrm{SE})$, than in whitebark pine, $54.1 \pm 4.01 \%$. Brood adult emergence did not differ significantly between hosts $(t=0.322, \mathrm{df}=14, p=0.752$, Fig. $1 \mathrm{E})$ and averaged $39.5 \pm 7.75$ brood per gallery in lodgepople pine and $35.9 \pm 6.71$ in whitebark pine. Sex ratio $(50 \%$ females in lodgepole pines; $48 \%$ females in whitebark pine) did not differ between the two host species $(t=0.31$ $\mathrm{df}=14, p=0.761)$.

Brood Adult Condition. Host species did not significantly influence brood adult size $(t=0.598, \mathrm{df}=14, p=0.201$, Fig. $1 \mathrm{~F})$, mass $(t=1.035, \mathrm{df}=14, p=0.318$, Fig. $1 \mathrm{G})$ or fat content $(t=1.41 \mathrm{df}=14, p=0.181$, Fig. $1 \mathrm{H})$. Average female brood adult pronotal width was $2.1 \pm 0.05$ $\mathrm{mm}$ in beetles from lodgepole pine and $2.0 \pm 0.05 \mathrm{~mm}$ in brood from whitebark pine. Nonetheless, brood adults tended to be slightly heavier in whitebark pine $(4.80 \pm 0.362 \mathrm{mg})$ than in lodgepole pines $(4.44 \pm 0.150 \mathrm{mg})$ while brood adults from lodgepole pine tended to have slightly higher fat content $(37 \pm 2.3 \%)$ than did those from whitebark pine $(33 \pm 1.2 \%)$.

\section{Discussion}

$$
\text { Drawing inferences about host quality from results based on rearings in cut bolts }
$$
requires caution because the host environment is undoubtedly very different in cut bolts compared to trees attacked naturally, especially insofar as host defences are concerned. Host material was collected for this experiment at the end of September, and although it is not unusual for mountain pine beetles to initiate attacks in September in Alberta (D.W. Langor, 
258 phloem hardening, the process whereby sieve and associated cells in the phloem die and are

259 replaced by callose, would have been more advanced in these bolts than in naturally attacked

260 trees (Alfiere and Evert 1968). Although phloem hardening has not been explicitly compared

261 between whitebark and lodgepole pines, this process is essentially similar between hard and

262 soft pines (Alfiere and Evert 1968). Bolts were sealed with wax to reduce moisture loss

263 associated with this hardening, as well as to offset the accelerated drying caused by

264 experimental conditions. Starch, nitrogen, lipid and mineral levels do not decrease as phloem

265 hardens (Haack and Slanksy 1987); however, carbohydrate levels, and potentially other

266 nutrient levels maybe be reduced in sub-corticle tissues in cut bolts compared to live trees

267 (Dunn and Lorio 1992). Nonetheless, such rearing experiments can provide useful insights

268 concerning host effects on beetles (e.g. Langor and Spence 1991).

269 Bolts were collected for our study from only ten trees of each species from a single

270 stand, although the number of trees used is relatively large compared to other mountain pine

271 beetle rearing studies (e.g. Bentz et al. 2001). Nonetheless, it is possible that these results

272 were influenced by host conditions specific to a single stand, and it would be inappropriate to

273 assert that they reflect what occurs across the broad geographic ranges of whitebark pine or

274 lodgepole pine. This is particularly true for lodgepole pine, which exhibits enormous

275 variability in 'chemotype' across its distribution (Clark et al. 2010). Thus, while the results of

276 our localized study cannot be extrapolated broadly, they do highlight real host-associated

277 patterns in beetle success that are valuable for designing future research and are part of a

278 larger scale study of mountain pine beetle survival, phenology and natural enemy abundance

279 in whitebark pines in Alberta (Esch 2012).

280 Observing mountain pine beetle behavior led Hopkins (1916) to formulate his famous

281 host-selection principle, which states that "a species which breeds in two or more hosts will

282 prefer to continue to breed in the host to which it has become adapted." This theory has 
283 existed in many incarnations and has been vigorously debated over the past century

284 (Reviewed in, Barron 2001). From this, we might expect that beetles would prefer and be 285 better adapted to develop in lodgepole pines in this study, because it was the host tree for all 286 parental beetles. Though a number of studies failed to validate this principle amongst the bark 287 beetles (See Barron 2001), it is evident that rapid, genetic isolation of mountain pine beetles 288 can occur within one host species over a few generations (Langor and Spence 1991). It is 289 likely that the beetles higher gallery success in lodgepole pine was due to a combination of 290 conditioned, genetic, and host quality related effects (Barron 2001), though untangling these 291 factors was not possible in this study. Data presented here lends support to Hopkin's host292 selection principle, as it is formulated above. However, it should also be noted that brood production and brood adult condition were not better in lodgepole pines, the host from which

294 the parents originated. This suggests that host quality, regardless of parental origin, may also 295 play an important role in beetle reproductive output and condition.

296 Egg gallery success was greater in lodgepole pine, with a tendency to increase with 297 phloem thickness in both hosts. These patterns could in part be explained by the parental effects described above and/or by differences between host species. Pioneer females are more

299 likely to construct egg galleries on larger trees that tend to have thicker phloem (Roe and 300 Amman 1970). Gallery initiation is also partially controlled by gustatory and olfactory

301 feedback from chemical properties of host tissues, with particular compounds known to 302 attract or repel beetles (Raffa and Berryman 1982). Differences in composition of 303 monoterpenes, a dominant class of insect-related defensive compounds found in the subcortical tissues of pines, have been found between whitebark and lodgepole pines (Raffa et al.

305 2013, Bentz et al. 2015). In no-choice assays, Raffa et al. (2013) found beetles entered

306 whitebark pine and lodgepole pine equally readily. Under natural conditions, mountain pine 307 beetles preferentially attack lodgepole pines over whitebark pines (Raffa et al. 2013, Bentz et 
308 al. 2015) while other studies failed to find significant differences in host preferences (Baker

309 et al. 1971, Six and Adams 2007). Though the no choice assays conducted in this study do

310 not replicate the full series of events occurring during natural attack, our data support the

311 consensus of the most robust data that mountain pine beetles may show some preference for

312 lodgepole pine over whitebark pine.

313 Brood production, brood adult condition and gallery characteristics, except larval

314 gallery density, did not differ significantly between the two host species. Other studies show

315 no significant difference in mountain pine beetle brood production between these two hosts in

316 the field (Esch 2012, Bentz et al. 2014, 2015, Dooley et al. 2014) or laboratory experiments

317 (Amman 1982) while one laboratory rearing study showed greater brood production in

318 lodgepole pine compared to whitebark pine (Gross 2008). Some field (Bentz et al. 2015) and

319 laboratory experiments (Gross 2008) showed brood adults were significantly larger when

320 they developed in whitebark pine compared to lodgepole pine, while Amman (1982) showed

321 similar results, however, the differences were not statistically significant. Mountain pine

322 beetle larval galleries are more densely spaced in trees with thicker phloem (Amman and

323 Cole 1983). The greater larval gallery density observed may have simply reflected the greater

324 proportion of successful egg galleries in whitebark pines in bolts with thick phloem. The

325 absence of large differences in brood production and survival, brood adult condition and sex

326 ratio measured in this study suggest that the sub-cortical environment of these two hosts

327 differed little in terms of nutritional properties, or that any such differences had little effect

328 on the developing brood.

329 Mountain pine beetle nutrition is also mediated by symbiotic ophiostomatelean fungi

330 and other microorganisms (Ayres et al. 2000, Myrholm and Langor 2015). Though these

331 relationships are beyond the scope of this paper, it may be worth noting that in a separate

332 study, performance of three fungal species did not vary significantly in live lodgepole pine 
versus whitebark pine trees (E. D. Esch and A. V. Rice unpublished data). It is unlikely that

334 the limited host effects on mountain pine beetle in this experiment can be explained by 335 differences in fungal performance.

336 Conclusions. Mountain pine beetles were less successful at initiating egg galleries on 337 whitebark pine bolts than on lodgepole pine bolts in our study. Though data presented here 338 are limited, and do not simulate the conditions whereby host selection occurs naturally, they

339 lend support to observations the beetle prefers lodgepole pines over whitebark pines, and 340 suggest that this pattern may hold true in the east slopes of the Rocky Mountains of southern

341 Alberta. However, the limited influence of host species on the majority of parameters

342 measured in this study and observed elsewhere indicates that host tree species is not the most 343 important factor affecting reproductive output or brood adult condition. In studies that show 344 significant influence of host species on reproductive output or brood adult condition, these 345 differences may be due to the confounding effects of phloem thickness (e.g. Amman 1982, 346 Langor 1989). Data presented here and elsewhere show no difference in phloem thickness 347 between the two host species (Baker et al. 1971, Esch 2012, Bentz et al. 2015) while others 348 show some thicker phloem in whitebark pines (Dooley et al. 2014). Given this, it is likely that 349 factors such as stand density, tree size (Perkins and Roberts 2003), white pine blister rust 350 (Cronartium ribicola Fischer) infection severity (Six and Adams 2007, Dooley and Six 2015) 351 and climate (Logan and Powel 2001) will be more important in predicting growth and spread 352 of mountain pine beetle populations in subalpine forests than host tree species. Interaction 353 among these factors with respect to mountain pine beetle success in whitebark pine is yet to 354 be investigated fully and should be a priority for future research.

\section{Acknowledgements}

We thank Colin Bergeron, Stéphane Bourassa, Jeremy Fitzpatrick, Suzanne Abele, Philip Hoffman, Adrienne Rice, Christine Twerdoclib, Daryl Williams, Chris Williams, Colin 
Myrholm, Brooks Horne, Joyce Gould and Sherril Esch for their assistance in the laboratory and field. We also thank Jaime Pinzon, Guillaume Blanchet and Nadir Erbilgin for their feedback and advice, which greatly improved this manuscript. We acknowledge the Natural Sciences and Engineering Research Council, Alberta Conservation Association Grants in Biodiversity, Natural Resources Canada - Canadian Forest Service, Foothills Research Institute, and Alberta Environment and Sustainable Resource Development - Parks and Lands and Forests for financial support. 


\section{References}

ASRD and ACA (Alberta Sustainable Resource Development and Alberta Conservation Association). 2007. Status of the whitebark pine (Pinus albicaulis) in Alberta. ASRD, Alberta Wildlife Status Report No. 63.

Alfieri, F. J. and Evert, R. F. 1968. Seasonal development of the secondary phloem in Pinus. Am. J. Bot. 55(4): 518-528.

Amman, G. D. 1982. Characteristics of mountain pine beetle reared in four pine hosts. Environ. Entomol. 2(4): 590-593.

Amman, G. D. 1984. Mountain Pine beetle (Coleoptera: Scolytidae) mortality in three types of infestations. Environ. Entomol. 13(1): 184-191.

Amman, G. D. and Cole, W. E. 1983. Mountain pine beetle dynamics in lodgepole pine forests part II: Population dynamics. USDA, For. Ser., Gen. Tech. Rep., INT-145.

Arno, S. F. and Hoff, R. J. 1989. Silvics of whitebark pine. USDA For. Serv. Gen. Tech. Rep. INT-253.

Ayres, M. P., Wilkens, R. T., Ruel, J. J., Lombardero, M. J. and Vallery, E. 2000. Nitrogen budgets of phloem-feeding bark beetles with and without symbiotic fungi. Ecology. 81(8): 2198-2210.

Baker, B. H., Amman, G. D. and Trostle, G. C. 1971. Does the mountain pine beetle change hosts in mixed lodgepole and whitebark pine stands? USDA For. Serv. Gen. Tech. Rep INT-151.

Barron, A. D. 2001. The life and death of Hopkin's host-selection principle. J. Insect Behav. 14(6):725-731. 
Bentz, B. J., Logan, J. A., Amman, G. D. 1991. Temperature-dependant development of the mountain pine beetle (Coleoptera: Scolytidae) and simulation of its phenology. Can. Entomol. 123(05): 1083-1094.

Bentz, B. J. and Schen-Langenheim, G. 2007. The mountain pine beetle and whitebark pine waltz: Has the music changed? In Proceedings of the Conference Whitebark Pine: A Pacific Coast Perspective, Ashland Oregon, 27-31 August 2006. Edited by E. M. Goheen and R. A. Sniezko. USDA For. Ser. Portland, OR pp. 43-50.

Bentz, B. J., Logan, J. A. and Vandygriff, J. C. 2001. Latitudinal variation in Dendroctonus ponderosae (Coleoptera: Scolytidae) development time and adult size. Can. Entomol. 133(3): $375-387$.

Bentz, B. J., Régnière, J., Fettig, C. J., Hansen, E. M., Hayes, J. L., Hicke, J. A., Kelsey, R. G., Lundquist, J., Negrón, J. F. and Seybold, S. J. 2010. Climate change and bark beetles of the western United States and Canada: Direct and indirect effects. Bioscience 60(8): 602-613.

Bentz, B. J., Vandygriff, J., Jensen, C., Coleman, T., Maloney, P., Smith, S., Grady, A. and Schen-Langenheim, G. 2014. Mountain Pine Beetle Voltinism and Life History Characteristics across Latitudinal and Elevational Gradients in the Western United States. For. Sci. 60(3): 434-449.

Bentz, B. J., Boone, C. and Raffa, K. F. 2015. Tree response and mountain pine beetle attack preference, reproduction and emergence timing in mixed whitebark and lodgepole pine stands. Agric. Forest Entomol. 17(4): 421-432.

Bolker, B. J., Brooks, M. E., Clark, C. J., Geange, S. W., Poulsen, J. R., Stevens, M. H. H. and White, J. S. S. 2009. Generalized linear mixed models: a practical guide for ecology and evolution. Trends Ecol. Evol. 24(3): 127-135. 
Carroll, A. L., Taylor, S. W., Regniere, J. and Safranyik, L. 2004. Effects of climate change on range expansion by mountain pine beetle in British Columbia. In Mountain Pine Beetle Symposium: Challenges and Solutions. 30-31 October, 2003, Kelowna, BC. Edited by T. L. Shore, J. E. Brooks and J. E. Stone. Natural Resources Canada, Pacific Forestry Centre, Victoria, BC. pp. 223-232.

Cerezke, H. F. 1995. Egg gallery, brood production and adult characteristics of mountain pine beetle, Dendroctonus ponderosae Hopkins (Coleoptera: Scolytidae), in three pine hosts. Can. Entomol. 127(6): 955-965.

Clark, E. L., Carroll, A. L., and Huber, D. P. W. 2010. Differences in the constitutive terpene profile of lodgepole pine across a geographical range in British Columbia, and correlation with historical attack by mountain pine beetle. Can. Entomol. 142(6):557573.

Cole, W. E. and Amman, G. D. 1980. Mountain pine beetle dynamics in lodgepole pine forests part I: course of an infestation. USDA, For. Ser., Gen. Tech. Rep., INT-89. Committee on the Status of Endangered Wildlife in Canada. 2010. COSEWIC assessment and status report on the Whitebark Pine Pinus albicaulis in Canada. Available from www.sararegistry.gc.ca/status/status_e.cfm [Accessed 10 August 2012].

Cudmore, T. J., Björklund, N., Carroll, A. L. and Lindgren, B. S. 2010. Climate change and range expansion of an aggressive bark beetle: Evidence of higher beetle reproduction in I host tree populations. J. Appl. Ecol. 47(5): 1036-1043.

Cullingham, C. I., Cooke, J. E. K., Dang, S. Davis, C. S., Cooke, B. J. and Coltman, D. W. 2011. Mountain pine beetle host-range expansion threatens the boreal forests. Mol. Ecol. 20(10): 2157-2171. 
Dooley, E. M., Six, D. L., Powell, J. A. 2014. A comparison of mountain pine beetle (Coleoptera: Curculionidae, Scolytinae) productivity and survival in lodgepole and whitebark pine after a region-wide cold weather event. For. Sci. 60(2): 235-246.

Dooley, E. M. and Six, D. L. 2015. Severe white pine blister rust infection in whitebark pine alters mountain pine beetle (Coleoptera: Curculionidae) attack density, emergence rate, and body size. Environ. Entomol. 44(6):1455-1464.

Dunn, J. P. and Lorio, P. L. Jr. 1992. Effects of bark girdling on carbohydrate supply and resistance of loblolly pine to southern pine beetle (Dendroctonus frontalis Zimm.) attack. Forest Ecol. Manag. 50(3): 317-330.

Ellison, A. M., Bank, M. S., Clinton, B. D., Colburn, E. C., Elliot, K., Ford, C. R., Foster, D. R., Kloeppel, B. D., Knoepp, J. D., Lovett, G. M., Mohan, J., Orwig, D. A., Rodenhouse, N. L., Sobczak, W. V., Stinson, K. A., Stone, J. K., Swan, C. M., Thompson, J., Von Holle, B. and Webster, J. R. 2005. Loss of foundation species: Consequences for the structure and dynamics of forested ecosystems. Front. Ecol. Environ. 3(9): 479-486.

Esch, E. D. 2012. Interactions between the mountain pine beetle (Dendroctonus ponderosae Hopkins) and whitebark pine (Pinus albicaulis Engelmann). M. Sc. theses, Department of Renewable Resources, University of Alberta, Edmonton, Alberta.

Esch, E. D., Spence, J. R. and Langor, D. W. 2015. Saproxylic beetle (Coleoptera) diversity in subalpine whitebark pine and lodgepole pine (Pinaceae) trees killed by mountain pine beetles (Coleoptera: Curculionidae). Can. Entomol. (In press).

Furniss, R. L. and Carolin, V. M. 1977. Western Forest Insects. USDA For. Serv. Misc. Pub. No. 1339.

Furniss, M. M. and Schenk, J. A. 1969. Sustained natural infestations by the mountain pine beetle in seven new Pinus and Picea hosts. J. Econ. Entomol. 62(2): 518-519. 
Gibson, K., Skov, K., Kegley, S., Jorgensen, C., Smith, S. and Witcosky, J. 2008. Mountain pine beetle impacts in high-elevation five-needle pines: Current trends and changes. USDA For. Serv. No. R1-08-020.

Gross, D. 2008. Mountain pine beetle fecundity and offspring size differ among lodgepole pine and whitebark pine hosts. M. Sc. theses, Department of Wildland Resources, Utah State University, Logan, Utah.

Haack, R. A. and Slansky, F. Jr. 1987. Nutritional ecology of wood-feeing coleoptrea lepidoptera and hymenoptera, insect adaptations to woody environments. In Nutritional ecology of insects mites and spiders. Edited by F. Slansky Jr. and J. G. Rodriguez. Wiley and Sons, New York. pp. 449-486.

Hopkins, A. D. 1916. Economic investigations of the scolytid bark and timber beetles of North America. USDA Program of Work for 1917. doi: $\underline{10.1371 / \text { journal.pone. }}$ $\underline{0001736}$

Kurz, W. A., Dymond, C. C., Stinson, G., Rampley, G. J., Neilson, E. T., Carroll, A. L., Ebata, T. and Safranyik, L. 2008. Mountain pine beetle and forest carbon feedback to climate change. Nature. 452(7190): 987-990.

Langor, D. W. 1989. Host effects on the phenology, development, and mortality of field populations of the mountain pine beetle, Dendroctonus ponderosae Hopkins (Coleoptera: Scolytidae). Can. Entomol. 121(2): 149-157.

Langor, D. W. and Spence, J. R. 1991. Host effects on allozyme and morphological variation of the mountain pine beetle, Dendroctonous ponderosae Hopkins (Coleoptera: Scolytidae). Can. Entomol. 123(2): 395-410.

Logan, J. A., Macfarlane, W. W. and Willcox, L. 2010. Whitebark pine vulnerability to climate change induced mountain pine beetle disturbance in the Greater Yellowstone Ecosystem. Ecol. Appl. 20(4): 895-902. 
Logan, J. A. and Powell, J. A. 2001. Ghost forests, global warming, and the mountain pine beetle (Coleoptera: Scolytidae). Am. Entomol. 47(3): 160-172.

Lyon, R. L. 1958. A useful secondary sex character in Dendroctonus bark beetles. Can. Entomol. 90(10): 582-584.

Myrholm, C. L. and Langor, D.W. 2014. Assessment of impact of ophiostomatalean fungal symbionts on mountain pine beetle performance on a jack pine diet using a novel in vitro rearing method. [online] Can. Entomol. (In press). doi http://dx.doi.org/ 10.4039/ tce. 2015.28

Perkins, D. L. and Roberts, D. W. 2003. Predictive models of whitebark pine mortality from mountain pine beetle. For. Ecol. Manage. 174(3): 495-510.

Pinheiro, J., Bates, D., DebRoy, S., Sarkar, D. and the R Core Team (2008). 2008. nlme: Linear and Nonlinear Mixed Effects Models. R package version 3.1-90. Available from http://cran.r-project.org/web/packages/nlme/index.html [accessed on 15 December 2014].

R Development Core Team. 2013. R: A language and environment for statistical computing. R Foundation for Statistical Computing, Vienna, Austria. ISBN 3-900051-07-0. Avaiable from http://www.R-project.org/ [accessed on 15 December 2014].

Raffa, K. F. and Berryman, A. A. 1982. Gustatory cues in the orientation of Dendroctonus ponderosae (Coleoptera: Scolytidae) to host trees. Can. Entomol. 114(2): 97-104.

Raffa, K. F., Powell, E. N. and Townsend, P. A. 2013. Temperature-driven range expansion of an irruptive insect heightened by weakly coevolved plant defences. Proc. Natl. Acad. Sci. USA. 110(6): 2193-2198.

Roe, A. L. and Amman, G. D. 1970. The mountain pine beetle in lodgepole pine forests. USDA For. Serv. Res. Pap. INT-71. 
Safranyik, L. and Carroll, A. L. 2006. The biology and epidemiology of the mountain pine beetle in lodgepole pine forest. In The mountain pine beetle a synthesis of biology, management and impacts on lodgepole pine. Edited by L. Safranyik and B. Wilson. Natural Resources Canada, Pacific Forestry Centre, Victoria, BC. pp. 3-66.

Safranyik, L., Carroll, A. L., Regniere, J., Langor, D. W., Riel, W. G., Shore, T. L., Peter, B., Cooke, B. J., Nealis, V. G. and Taylor, S. W. 2010. Potential for range expansion of the mountain pine beetle into the boreal forests of North America. Can. Entomol. 142(5): 415-422.

Six, D. L. and Adams, J. 2007. White pine blister rust severity and selection of individual whitebark pine by the mountain pine beetle (Coleoptera: Curculionidae, Scolytinae). J. Entomol. Sci. 42(3): 345-353.

Smith, R. H., Cramer, J. P., and Carpender, E. J. 1981. New record of introduced hosts for the mountain pine beetle in California. USDA, For. Ser., Gen. Tech. Rep., PSW-354.

Taylor, S. W. and Carroll, A. L. 2004. Disturbance, forest age, and mountain pine beetle outbreak dynamics in BC: A historical perspective. In Mountain Pine Beetle Symposium: Challenges and Solutions. 30-31 October, 2003, Kelowna, BC. Edited by T. L. Shore, J. E. Brooks and J. E. Stone. Natural Resources Canada, Pacific Forestry Centre, Victoria, BC. pp. 41-52.

Tomback, D. T., Arno, S. F. and Keane, R. E. 2001. The compelling case for management intervention. In Whitebark pine communities ecology and restoration. Edited by D. T. Tomback, S. F. Arno and R. E. Keane. Island Press, Washington, DC. pp. 3-25.

Venables, W. N. and Ripley, B. D. 2002. Modern Applied Statistics with S Fourth Edition. Springer, New York. ISBN 0-387-95457-0. Available from http://cran.rproject.org/web/ packages/MASS/index.html. 
Wood, S. L. 1982. The bark and ambrosia beetles of North and Central America (Coleoptera: Scolytidae), a taxonomic monograph. Great Basin Nat. No. 6.

Zuur, A. F., Ieno, E. N., Walker, N., Saveliev, A. A. and Smith, G. M. 2009. Mixed effects models and extensions in ecology with R. Springer, New York. 


\section{Figure Captions}

Fig. 1: Boxplots (horizontal bar indicating the median, bottom and top of boxes indicating the $2^{\text {nd }}$ and $3^{\text {rd }}$ quartiles, respectively, lower and upper whiskers indicating $1^{\text {st }}$ and $4^{\text {th }}$ quartiles, respectively, points indicating outliers) of life history characteristics of mountain pine beetles reared in lodgepole pine and whitebark pines bolts. Panels show: A) the average proportion of attempted egg galleries that were successfuly established per tree, B) the average length of egg galleries $(\mathrm{cm})$ per tree, C) the average density of larval galleries per $\mathrm{cm}$ of egg gallery length per tree, D) the average proportion of brood surviving from first larval instar to emerging adult per tree, E) the average number of brood emerging per tree, F) the average pronotal width $(\mathrm{mm})$ of female brood adults per tree, $\mathrm{G})$ the average mass $(\mathrm{mg})$ of female brood adults per tree and $\mathrm{H}$ ) the average fat content (percent of mass) of female brood adults per tree. A * indicates a statistically significant difference between host species $(p<0.05)$. 

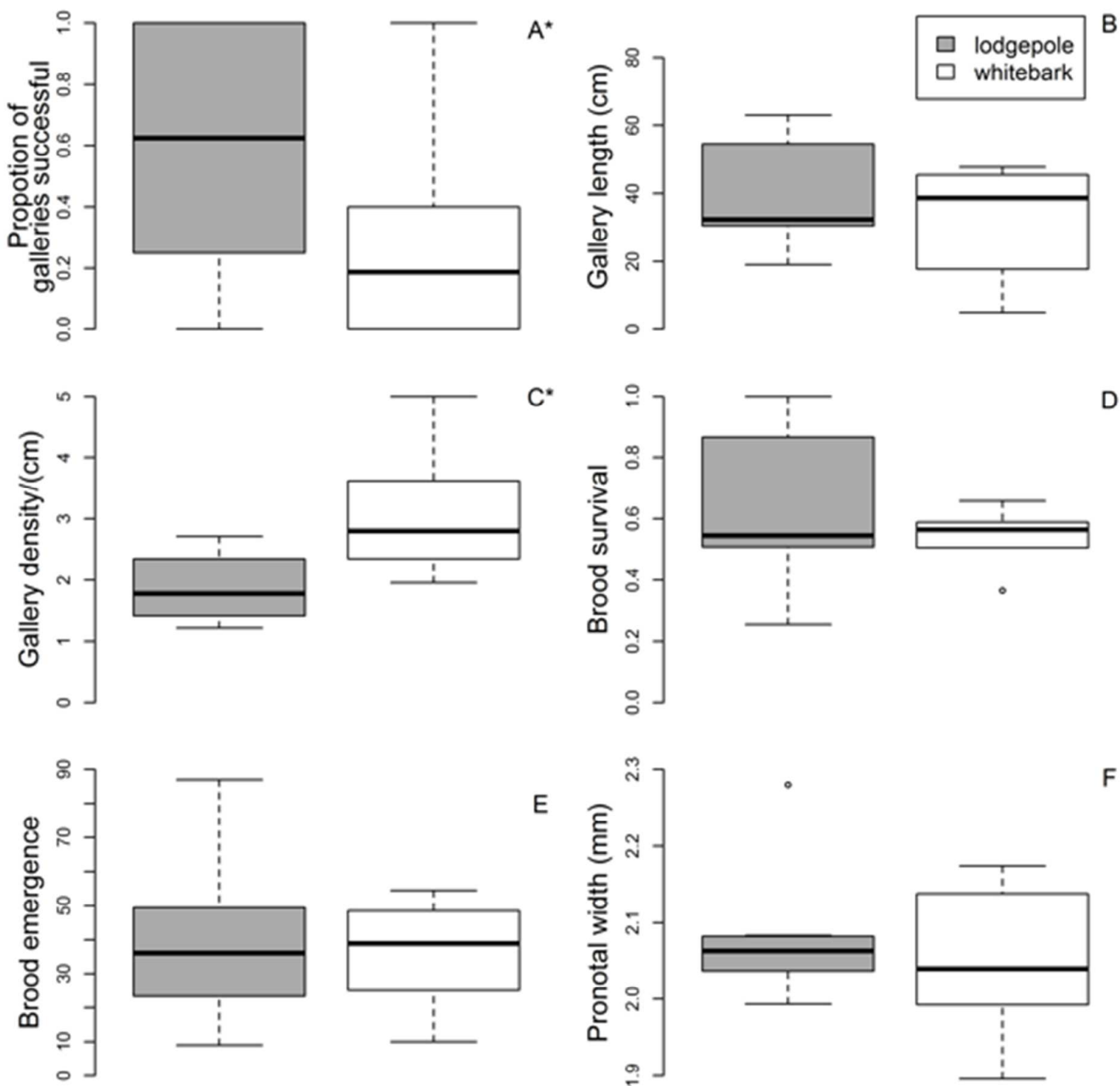

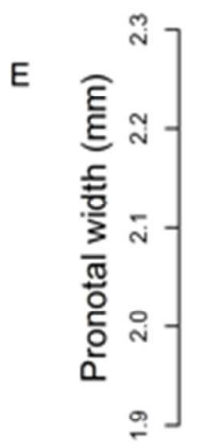
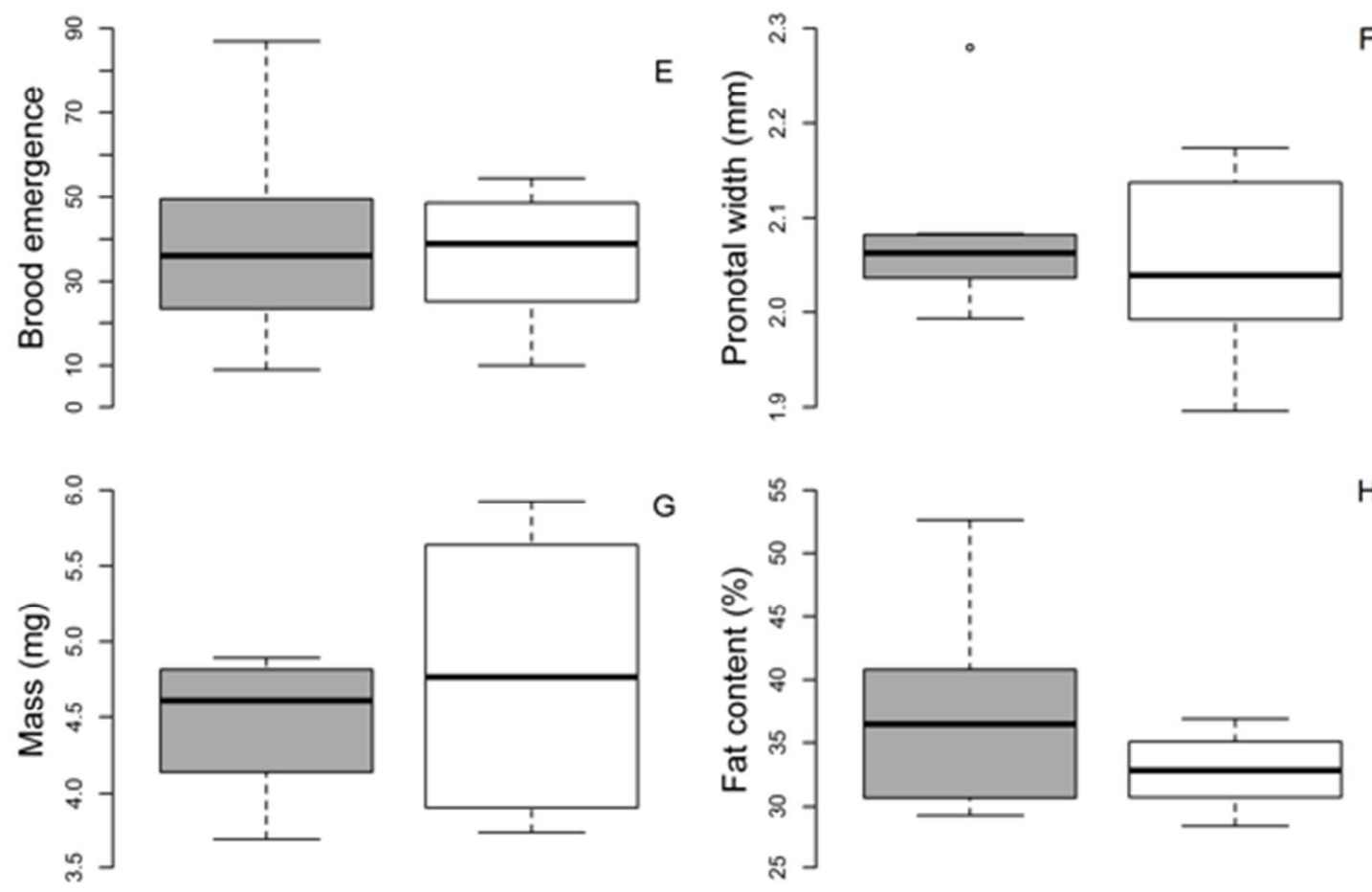

H 
